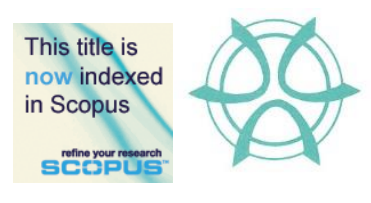

PLANNING MALAYSIA:

Journal of the Malaysian Institute of Planners

VOLUME 15 ISSUE 4 (2017), Page 13 - 20

\title{
STREET DESIGN AND WOMEN'S SAFETY PERCEPTION
}

\author{
Suhaila Abdul Rashid ${ }^{1}$, Mohammad Hussaini Wahab ${ }^{2}$, \& Wan Nurul Mardiah \\ Wan Mohd Rani ${ }^{3}$ \\ ${ }^{1,2,3}$ UTM Razak School of Engineering and Advanced Technology \\ UNIVERSITI TEKNOLOGI MALAYSIA
}

\begin{abstract}
Urbanization is a process that creates many opportunities as well as threats. It is a process that will keep on continuing as population rate, migration, economic and social pattern are changing. Along with urbanization, demand for sustainable development and public space is crucial. Streets are important public space in a city. It is a network for many kind of activities. Design of streets affects the way people use it as well as their perception on safety. As a public space, safety is an important factor to consider. A safe public space will create a liveable environment. Feeling safe is important for human being due to the fact the built environment does affect our perception. Gender plays a role in safety perception where women perceive their environment differently. This study focuses on the importance of street as public space in contributing towards safety perception. In order to evaluate the phenomenon, a mixed method approach was adopted. Four streets in the city centre which are important public space with trading activities, connected to educational institution, offices and other economic activities were chosen. 120 questionnaire were distributed and direct observation were conducted in order to evaluate the phenomenon. Findings revealed that physical elements in the street do affect safety perception.
\end{abstract}

Keyword: Public space, sustainable urban design, street design, safety perception

Date Received: $11^{\text {th }}$ May 2017

Date of Acceptance: $13^{\text {th }}$ November 2017 
Suhaila Abdul Rashid, Mohammad Hussaini, \& Wan Nurul Mardiah

Street as Public Space and Safety Perception

\section{INTRODUCTION}

Urbanization rate are increasing at global level and in Malaysia alone it is increasing (World Bank, 2015; Masron et al, 2012) especially in major cities like Kuala Lumpur, Georgetown and Johor Bahru (World Bank, 2015). During urbanization process, built environment, including public space, will definitely be changing according to the demand and needs of the population, and the economic and political scenarios. The way we design our built environment are affecting social aspect, especially the design of public space where the current trend has led to private ownership, and affecting usage and sense of place. Public space can encourage socially acceptable or unacceptable behavioural responses, therefore it should be designed to become the physical sign of cultural expectations (Thomas, 2002). A sense of feeling safe in a public space has a great influence on perception. Stanley et al. (2012) found that the form and function of public space vary based on particular cultural arrangements, but still having similar features. It needs to be inviting, lively, attractive and comfortable. According to Soholt (2004), there are three main criteria for public space; protection, comfort and enjoyment.

Public space is an important element of urban design, which comprises street and square. However, in Malaysian context, streets are more dominant in terms of usage due to several factors, especially due to our hot and humid weather. For centuries, street acts as public space. During the medieval period it was a social and political space as well as marketplace. Street also formed the cities through its grid iron layout. However, over the years, street design has changed due to advancement in technology as well as our increasing dependency on motorised vehicles. The grid iron layout which was dominant previously has given way to long and wide street sandwiched by tall buildings. This has made street became less pedestrian-friendly and resulting in diminishing the role of street as a public realm. Rudlin et al. (2009) found that the traditional street are more robust and attract more people to urban area.

Street has been considered as a 'symbol' of public space and has always been the centre of attention. According to Mehta (2008), street has been recognised as public space by modern urban societies rather than the town square or the piazza. Design of the street is important as this is where public life happen, where people mingle and do their everyday activities from trading to leisure. In order to maintain sense of place and public life, it needs to be safe and comfortable for all. It should be free from crime and people should feel free to use it with no fear of their safety (Carmona et al., 2003). Safety is major issues in the cities not only in developing country like Malaysia but also in developed country (UN Habitat, 2007).

Research shows that fear is more dominant among women where they feel more vulnerable compared to men especially when being in the street at night. However, with the changing and advancement in many aspects of life, 
PLANNING MALAYSIA

Journal of the Malaysia Institute of Planners (2017)

women are changing the demographic in the city. Cities are occupied not only by men but also women for many purposes. Making public space safer for women is a major step ahead towards enhancing women's access to these spaces. Due to this, UN Women, UNICEF and UN Habitat have jointly launched the 'Safe and Sustainable Cities for All' programme, involving many countries. UN Women Safe Cities Global Initiative has also taken steps to overcome safety issue especially for women in public spaces. Street in the city is an important public space which women use especially the shopping street even though the design varies according to locality and culture.

According to survey by United Nations in 2012, it was found that women in developed country feel unsafe in their environment. In London, a 2012 poll found that $43 \%$ of young women had experienced street harassment in the past year. However, the number of women that appear in the public realm, during the day and especially at night, is an indicator of the health of a society and the safety and liveability of a city (Bloomingrock, n.d.). Thus, the design of the built environment, especially public space, must consider the safety of women so that more of them will feel safe, welcomed and comfortable using public space.

\section{RESEARCH BACKGROUND}

The importance of safer street as public space is for all, not just specifically for women. However, since women are more vulnerable and perceive the environment differently, more attention should be given for them. In Malaysia, sustainable development is a continuing process along with rapid development. According to Saadatian et al. (2011), even though there are various initiatives have been taken, there are still weaknesses in the realm of sustainable development.

Perception of safety is influenced by many factors such as social, economic, cultural, environment and demographic (Boulange, 2011) and women were constantly reported as registering more fear of crime than men. Gender has been found consistently and strongly as an important factor associated with fear of crime. Women in general feel fearful (UN Women, 2015) compared to men (Grabosky, 1995). Rapoport (1977) highlighted that perception is the key process to connect people within the surrounding environment related to man and environment.

\section{METHODOLOGY}

This study adopted questionnaire survey as the technique to obtain primary data. 120 questionnaires were distributed to respondents who were chosen through convenient sampling in the study area. Additionally, site observation was also conducted by the researchers to corroborate the findings from the questionnaire survey. 
Suhaila Abdul Rashid, Mohammad Hussaini, \& Wan Nurul Mardiah

Street as Public Space and Safety Perception

The case study area was four significant streets located in Kuala Lumpur. These were Jalan Benteng, Jalan Melaka, Jalan Tun Perak and Jalan Melayu. These four streets are connected to Masjid Jamek LRT station and are the focal points for various types of activities, including historical landmarks such as the Masjid Jamek, that attract crowd to the area.

\section{FINDINGS}

\section{Physical Elements That Affect Safety Perception}

Findings from the questionnaire survey showed that majority of respondent (70\%) agreed that physical elements in the area affect safety perception among women. These elements were visibility, land use mix, lighting, accessibility, orientation, signage and presence of vibrant activities.

On-site observation revealed that some of the elements that affect safety perception in the area were in less than sufficient state. However, the condition varies between streets. For instance, Jalan Melayu has a very good mixture of land use, accessibility, orientation and activities, but lacking in terms of visibility, lighting, signage and CCTV. Similarly, other streets in the area have different state of condition of the elements that affect safety perception. The current condition of the elements are as stated in Table 1 below.

Table 1 Physical elements that affect safety perception

\begin{tabular}{|c|c|c|c|c|}
\hline \multirow[b]{2}{*}{ Elements } & \multicolumn{4}{|c|}{ Street } \\
\hline & Jalan Melayu & Jalan Melaka & $\begin{array}{c}\text { Jalan Tun } \\
\text { Perak }\end{array}$ & Jalan Benteng \\
\hline Visibility & Obstructed & Fully visible & Fully visible & Obstructed \\
\hline $\begin{array}{l}\text { Mixture of } \\
\text { land use }\end{array}$ & $\begin{array}{l}\text { Variety of } \\
\text { uses }\end{array}$ & $\begin{array}{l}\text { Less variety } \\
\text { of uses }\end{array}$ & $\begin{array}{c}\text { Variety of } \\
\text { uses }\end{array}$ & $\begin{array}{c}\text { Less variety of } \\
\text { uses }\end{array}$ \\
\hline Lighting & $\begin{array}{l}\text { Lack of } \\
\text { lighting }\end{array}$ & $\begin{array}{l}\text { Enough } \\
\text { lighting }\end{array}$ & $\begin{array}{l}\text { Enough } \\
\text { lighting }\end{array}$ & $\begin{array}{l}\text { Lack of } \\
\text { lighting }\end{array}$ \\
\hline Accessibility & Accessible & Accessible & Accessible & Accessible \\
\hline Orientation & Fair & $\begin{array}{l}\text { Facing the } \\
\text { street }\end{array}$ & $\begin{array}{l}\text { Facing the } \\
\text { street }\end{array}$ & Poor \\
\hline Signage & $\begin{array}{l}\text { Lack of } \\
\text { signage }\end{array}$ & $\begin{array}{l}\text { Lack of } \\
\text { signage }\end{array}$ & $\begin{array}{l}\text { Lack of } \\
\text { signage }\end{array}$ & $\begin{array}{l}\text { Lack of } \\
\text { signage }\end{array}$ \\
\hline $\begin{array}{l}\text { Vibrant } \\
\text { activities }\end{array}$ & Vibrant & Less vibrant & Vibrant & Less vibrant \\
\hline $\begin{array}{l}\text { Provision of } \\
\text { CCTV }\end{array}$ & Lacking & Moderate & Lacking & Lacking \\
\hline
\end{tabular}

Source: Fieldwork, 2016 
Majority of respondents agreed that visibility is important in perceived safety, but through observation survey it was found that two streets, Jalan Benteng and Jalan Melayu, have poor level of visibility.

To be safe, places must also be well used. For this to happen, good urban design should address connectivity not in isolation, but alongside other qualities such as the mixture of activities and land uses.

The validity of findings from questionnaire survey was also corroborated when it was observed that women change their route when the environment was less safe to their perception. This has been observed at Medan Pasar where most of the five-foot walkway were crowded by foreign men. One snatch crime was also witnessed and this indicates that the area is not safe for women even during daytime.

Majority of the respondents also agreed that lighting is important and through observation, it was found that perception data is consistent. Some area do have lighting but poor visibility due to lighting quality and shadow due to lighting being blocked by tree canopy.
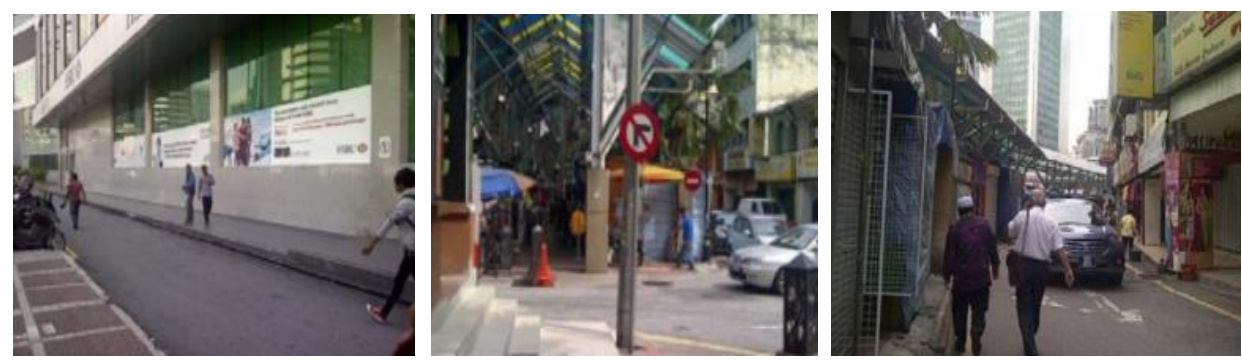

Figure 1 Streets which are not visible for pedestrian -Jalan Benteng and Jalan Melayu Source: Fieldwork, 2015

Visibility was also affected by building design. Jalan Benteng and Jalan Melayu were poor in terms of visibility due to the design of the building as well as the activities along these streets. This has affected perception of safety especially at night. Jalan Melayu for example is a traditional street, but due to changes in economic and activities, new structures were added without considering safety factor. Jalan Benteng which is connected to Jalan Tun Perak is visible but poor in terms of surveillance since the street is fronted by the rear of the buildings and a river. Being lacking in terms of surveillance has attracted social incivilities such as beggars and homeless persons to the area. 
Suhaila Abdul Rashid, Mohammad Hussaini, \& Wan Nurul Mardiah

Street as Public Space and Safety Perception

Table 2 Comparison between questionnaire survey and on-site observation results

\begin{tabular}{lll}
\hline Elements & Questionnaire (N=120) & Observation \\
\hline Hidden walkway & $95 \%$ & Relevant \\
Underground passageway & $86 \%$ & Not relevant \\
Single land use & $78 \%$ & Relevant \\
Unkempt landscape & $85 \%$ & Not relevant \\
Lack of lighting & $90 \%$ & Relevant \\
Graffiti & $85 \%$ & Not relevant \\
Litter & $92 \%$ & Not relevant \\
Poor maintenance & $90 \%$ & Not relevant \\
\hline
\end{tabular}

Source: fieldwork, 2016

Results from questionnaire survey indicated that women feel unsafe when presented with negative elements in their environment such as litter and graffiti with over $80 \%$ of respondents were in agreement. However, from observation, it was found that these two variables were insignificant towards perceived safety. Women were seem unfettered by litter and graffiti in the area.
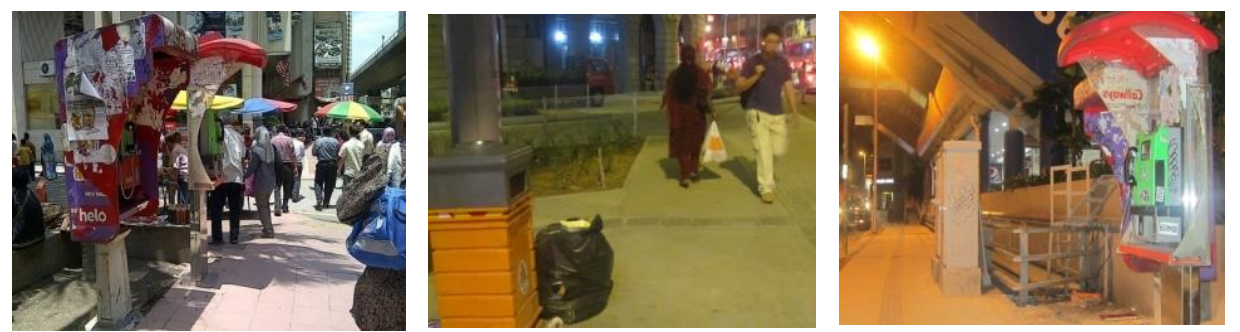

Figure 2: Physical incivilities

Source: Fieldwork, 2015

\section{SOCIAL ELEMENTS}

Social elements like crowding, street beggars and homeless people have been found to be among the factors that affect safety perception. The study area is attracting social incivilities due to the urban design and condition of the area where some parts were not properly maintained. The presence of homeless people and street beggars add to the social incivilities of the area and create an environment which is perceived as safe for other users, especially by women and at night. 

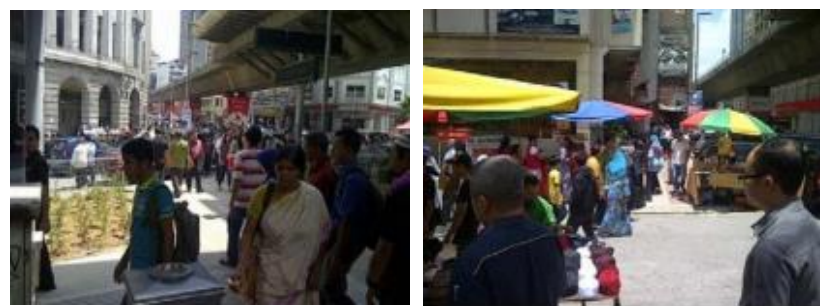

Figure 4: Social incivilities

Source: Fieldwork, 2015

\section{CONCLUSION}

Findings from this study showed that both physical elements and social elements affect safety perception among female users of public space such as the streets. From this study, it shows that physical elements of the street are affecting perception of users in different ways according to location and time. Streets as public space are populated area; therefore, they should be designed with safety aspect in mind. Besides the physical elements, social elements also need to be addressed in order to increase safety perception and to encourage the use of street as public space. As the country moving towards developed nation, a liveable aspect of life which include safety should be the priority. Future study should explore more on the relationship of physical elements and perception according to local criteria and demographic background.

\section{ACKNOWLEDGEMENTS}

This study was made possible with support from UTM Razak School of Engineering and Advanced Technology.

\section{REFERENCES}

Bloomingrock (n.d.). Designing safe cities for women, Retrieved from https://www.smartcitiesdive.com

Boulange, C. (2011). The effect of urban crime and perceived safety on urban levels of physical activity: a review. World Health Organisation Kobe Centre for Health Development. Retrieved from www.who.int

Carmona, M., Heath, T., Oc, T. \& Tiesdell, S. (2003). Public places-urban spaces: The dimensions of urban design. UK: Architectural Press.

Grabosky, P. N. (1995). Fear of crime and fear reduction strategies. Trends \& Issues in Crime and Criminal Justice, 44, 41-60.

Masron, T., Yaakob, U., Ayob, N.M., \& Mokhtar, A.S. (2012). Population and spatial distribution of urbanisation in Peninsular Malaysia 1957-2000. Geografia: Malaysian Journal of Society and Space, 8(2), 20-29.

Mehta, V. (2008). Walkable streets: Pedestrian behaviour, perceptions and attitudes. Journal of Urbanism: International Research on Placemaking and Urban Sustainability, 1(3). http://dx.doi.org/10.1080/17549170802529480 
Suhaila Abdul Rashid, Mohammad Hussaini, \& Wan Nurul Mardiah

Street as Public Space and Safety Perception

Rapoport, A. (1977). Human aspects of urban form: Towards a man-environment approach to urban form and design. New York: Pergamon Press.

Rudlin, D., \& Falk, N. (2009). Sustainable urban neighbourhood, building the $21^{\text {st }}$ century home. London: Architectural Press.

Saadatian, O., Lim, C. H., Sohif, M., \& Salleh, E. (2011). Sustainable development in Malaysia - planning and initiatives. Recent Researches in Chemistry, Biology, Environment and Culture. Retrieved from https://www.researchgate.net/publication/228532721_Sustainable_Developme nt_in_Malaysia-Planning_and_Initiatives.

Stanley, B.W., Barbara L.S., Katrina, L.J. \& Michael E.S. (2012). Urban open spaces in historical perspective: A transdisciplinary typology and analysis. Urban Geography, 33(8), 1089-1117.

Soholt, H. (2004, June). Life, spaces and buildings - turning the traditional planning process upside down. 5th International Conference on Walking in the 21 st Century, June 9-11 2004, Copenhagen, Denmark.

Thomas, D. (2002). Architecture and the urban environment: A vision for new age, London: Architectural Press.

UN Habitat (2007). Enhancing urban safety and security: Global report on human settlements 2007. London: Earthscan.

UN Women (2015). Safe cities and safe public spaces. Retrieved from http://www2.unwomen.org/-/media/field\%20office\%20eseasia/docs /publications/2016/10/3un\%20women-safecities-brief-test.pdf?la=en\&vs=919.

World Bank (2015). Malaysia economic monitor, December 2015 - immigrant labor. Retrieved from http://www.worldbank.org 